\title{
Políticas comercial e cambial, vulnerabilidade externa e crescimento econômico: a experiência da economia brasileira a partir dos anos 1980
}

Fernando Ferrari Filho Professor titular do Departamento de Ciências Econômicas da UFRGS e pesquisador do CNPq

Gustavo Teixeira Ferreira da Silva Mestrando do PPGE-UFRGS e professor do Departamento de Economia da UNESC

Samira Schatrmann Mestranda do PPGE-UFRGS e bolsista de pesquisa do IPEA

\section{Palauras-chave \\ políticas comercial e cambial, vulnerabilidade externa, crescimento econômico.}

\section{Classificação JEL F10, F21, F41.}

\author{
Key words \\ Trade and exchange rate policies; \\ external vulnerability; \\ economic growth.
}

JEL Classification F10, F21, F41.

\section{Resumo}

Inicialmente, o artigo analisa as estratégias e a performance das políticas comercial e cambial da economia brasileira a partir da década de 1980 e, em especial, no período pós-Plano Real. Em segundo lugar, busca relacionar os diferentes graus de vulnerabilidade externa do período com o comportamento das taxas de crescimento econômico do Brasil. Por fim, propõe uma agenda alternativa de políticas econômicas para o Brasil que, além de estar alicerçada em políticas monetárias e fiscais contracíclicas, tenha como objetivo a operacionalização de políticas cambial e industrial e de mecanismos de controle de capitais, condições necessárias para equilibrar de forma intertemporal o setor externo e assegurar, assim, bases para uma trajetória de crescimento econômico sustentável.
Para Vera Regina, in memorian

\section{Albstract}

First, the paper analyses the performance of the trade and exchange rate policies in Brazilian economy since the 1980s, specifically in the postReal Plan period. Second, it attempts to relate the different degrees of external vulnerability of the period with the behavior of economic growth rates in the Brazilian economy. Third, it proposes an economic agenda, based on counter-cyclical monetary and fiscal policies, a managed exchange rate, industrial policy and capital controls, to mitigate or eliminate Brazilian external vulnerability, which is so important to assure sustainable growth rate for Brazilian economy. 


\section{Introdução}

Ao longo dos anos 1980 e 1990, a economia brasileira conviveu com estratégias de políticas econômicas substancialmente distintas: no início da década de 1980, a política econômica foi centrada na promoção das exportações e no controle de importações, objetivando, dessa maneira, assegurar megassuperávits comerciais, imprescindíveis tanto para mitigar a vulnerabilidade externa quanto estabilizar a relação dívida externa/PIB do país, principalmente após a crise cambial observada no início da referida década. A partir da segunda metade dos anos 1980 e, mais especificamente, após a adoção do Plano Real, a atenção da política econômica voltou-se sobretudo para a estabilização monetária. ${ }^{1}$

Independentemente das diferentes estratégias de políticas econômicas implementadas ao longo das últimas décadas, seja para equilibrar o balanço de pagamentos, seja para controlar a inflação, desde os anos 1980 a economia brasileira vem apresentando, em maior ou menor grau, situações de vulnerabilidade externa e incapacidade de crescer sustentavelmente.

Indo nessa direção, Thirlwall (1982), por exemplo, considera que a principal limitação de demanda agregada em uma economia aberta é aquela relacionada ao desequilíbrio do setor externo, balanço de pagamentos. Conforme seu modelo sugere, existe uma restrição, no longo prazo, do balanço de pagamentos sobre o crescimento econômico; ou seja, à medida que uma economia cresce mais que sua taxa de equilíbrio do balanço de pagamentos, a demanda por importações se eleva, ocasionando, como contrapartida, déficits cada vez maiores no balanço de pagamentos em transações correntes.

Nesse sentido, uma implicação simples de política econômica para qualquer país que queira elevar sua taxa de crescimento econômico consiste em mitigar a restrição que o balanço de pagamentos impõe à demanda agregada (Thirlwall, 2005). Para tanto, considerase que o Estado tem papel fundamental na promoção de políticas econômicas, tais como comercial, cambial e industrial, que possibilitam ao setor econômico, em especial o privado, participar de forma ativa no comércio internacional, a fim de superar as limitações de crescimento econômico do país.

Ao se observar os resultados do balanço de pagamentos em transações correntes, a inserção do setor externo brasileiro e a performance do PIB do Brasil ao longo das décadas de 1980, 1990 e

\footnotetext{
Nunca é demais salientar que, na segunda metade dos anos 1980 e início da década de 1990, houve algumas tentativas de estabilização monetária, como Plano Cruzado, em 1986, Plano Bresser, em 1987, Plano Maílson, em 1989, e Plano Collor, em 1990, que acabaram não logrando êxito no que diz respeito ao controle do processo inflacionário.
} 
Os referidos valores foram calculados tendo como base a Tabela 1, a Tabela 2 e a Tabela 3. nos anos 2000, é possível conjecturar que uma das prováveis causas para o baixo e instável crescimento do PIB esteja, em parte, relacionada ao grau de vulnerabilidade externa do país. Analisando-se, especificamente, os saldos comerciais, tem-se o seguinte: por um lado, nos anos 1990, o saldo acumulado da balança comercial caiu $57,1 \%$ em relação ao saldo nos anos 1980 - no período 1980-1989, o superávit comercial atingiu o montante de US\$ 86,0 bilhões, ao passo que, entre 1990 e 1999, a balança comercial acumulou um superávit de US\$ 36,9 bilhões - e a taxa média de crescimento do PIB caiu 0,8\% nos anos 1990 - entre 1980 e 1989, o PIB apresentou crescimento médio de $2,9 \%$ ao ano, enquanto nos anos
1990 o PIB médio anual cresceu $1,7 \% ;^{2}$ por outro, entre 2000 e 2008, o crescimento médio do PIB foi da ordem de 3,7\% ao ano, ao passo que o superávit acumulado da balança comercial foi de US\$229,4 bilhões.

Em suma, com base em uma análise comparativa das diferentes estratégias de políticas econômicas implementadas nas últimas décadas no Brasil, os resultados do setor externo - tendo como referências a balança comercial, o saldo de transações correntes e a participação das exportações brasileiras nas exportações mundiais e alguns indicadores de vulnerabilidade externa - e da atividade econômica produtiva parecem nos mostrar que há relação de causalidade

Tabela 1_ Taxa de crescimento do PIB

\begin{tabular}{|c|c|c|c|c|c|}
\hline Ano & $\%$ & Ano & $\%$ & Ano & $\%$ \\
\hline 1980 & 9,2 & 1990 & $-4,4$ & 2000 & 4,3 \\
\hline 1981 & $-4,3$ & 1991 & 1,0 & 2001 & 1,3 \\
\hline 1982 & 0,8 & 1992 & $-0,5$ & 2002 & 2,7 \\
\hline 1983 & $-2,9$ & 1993 & 4,7 & 2003 & 1,1 \\
\hline 1984 & 5,4 & 1994 & 5,3 & 2004 & 5,7 \\
\hline 1985 & 7,9 & 1995 & 4,4 & 2005 & 3,2 \\
\hline 1986 & 7,5 & 1996 & 2,2 & 2006 & 3.7 \\
\hline 1987 & 3,5 & 1997 & 3,4 & 2007 & 6,1 \\
\hline 1988 & $-0,1$ & 1998 & 0,0 & 2008 & 5,1 \\
\hline 1989 & 3,2 & 1999 & 0,3 & - & - \\
\hline
\end{tabular}


Tabela 2_Exportações, em US\$ bilhões

\begin{tabular}{|c|c|c|c|c|}
\hline Ano & PIB* & Exportações* & $\begin{array}{c}\text { Crescimento } \\
\text { percentual (\%) }\end{array}$ & $\begin{array}{l}\text { Participação } \\
\text { no PIB }(\%)\end{array}$ \\
\hline 1980 & 236,8 & 20,1 & 32,1 & 8,5 \\
\hline 1981 & 257,3 & 23,3 & 15,7 & 9,1 \\
\hline 1982 & 269,9 & 20,2 & $-13,4$ & 7,5 \\
\hline 1983 & 188,5 & 21,9 & 8,5 & 11,6 \\
\hline 1984 & 188,8 & 27,0 & 23,3 & 14,3 \\
\hline 1985 & 210,2 & 25,6 & $-5,1$ & 12,2 \\
\hline 1986 & 256,5 & 22,3 & $-12,8$ & 8,7 \\
\hline 1987 & 280,9 & 26,2 & 17,3 & 9,3 \\
\hline 1988 & 304,2 & 33,8 & 28,8 & 11,1 \\
\hline 1989 & 413,6 & 34,4 & 1,8 & 8,3 \\
\hline 1990 & 466,6 & 31,4 & $-8,6$ & 6,7 \\
\hline 1991 & 405,1 & 31,6 & 0,7 & 7,8 \\
\hline 1992 & 387,3 & 35,8 & 13,2 & 9,2 \\
\hline 1993 & 429,6 & 38,6 & 7,7 & 9,0 \\
\hline 1994 & 546,2 & 43,5 & 12,9 & 8,0 \\
\hline 1995 & 769,0 & 46,5 & 6,8 & 6,1 \\
\hline 1996 & 839,7 & 47,7 & 2,7 & 5,7 \\
\hline 1997 & 871,2 & 53,0 & 11,0 & 6,1 \\
\hline 1998 & 843,8 & 51,1 & $-3,5$ & 6,1 \\
\hline 1999 & 586,9 & 48,0 & $-6,1$ & 8,2 \\
\hline 2000 & 644,5 & 55,1 & 14,7 & 8,6 \\
\hline 2001 & 554,0 & 58,2 & 5,7 & 10,5 \\
\hline 2002 & 505,9 & 60,4 & 3,7 & 11,9 \\
\hline 2003 & 552,2 & 73,1 & 21,1 & 13,2 \\
\hline 2004 & 663,6 & 96,5 & 32,0 & 14,5 \\
\hline 2005 & 881,8 & 118,3 & 22,6 & 13,4 \\
\hline 2006 & $1.089,0$ & 137,8 & 16,5 & 12,7 \\
\hline 2007 & $1.333,6$ & 160,6 & 16,6 & 12,1 \\
\hline 2008 & $1.575,9$ & 197,9 & 23,2 & 12,6 \\
\hline
\end{tabular}

$(*)$ Valores em dólares correntes.

Fonte: SECEX. 
Tabela 3_ Importações, US\$ bilhões

\begin{tabular}{|c|c|c|c|c|}
\hline Ano & PIB & Importações" & $\begin{array}{c}\text { Crescimento } \\
\text { percentual }(\%)\end{array}$ & $\begin{array}{c}\text { Participação no } \\
\text { PIB (\%) }\end{array}$ \\
\hline 1980 & 236,8 & 23,0 & 26,9 & 9,7 \\
\hline 1981 & 257,3 & 22,1 & $-3,8$ & 8,6 \\
\hline 1982 & 269,9 & 19,4 & $-12,2$ & 7,2 \\
\hline 1983 & 188,5 & 15,4 & $-20,4$ & 8,2 \\
\hline 1984 & 188,8 & 13,9 & $-9,8$ & 7,4 \\
\hline 1985 & 210,2 & 13,1 & $-5,5$ & 6,3 \\
\hline 1986 & 256,5 & 14,0 & 6,8 & 5,5 \\
\hline 1987 & 280,9 & 15,0 & 7,2 & 5,4 \\
\hline 1988 & 304,2 & 14,6 & $-3,0$ & 4,8 \\
\hline 1989 & 413,6 & 18,3 & 25,0 & 4,4 \\
\hline 1990 & 466,6 & 20,7 & 13,1 & 4,4 \\
\hline 1991 & 405,1 & 21,0 & 1,8 & 5,2 \\
\hline 1992 & 387,3 & 20,5 & $-2,3$ & 5,3 \\
\hline 1993 & 429,6 & 25,3 & 22,9 & 5,9 \\
\hline 1994 & 546,2 & 33,1 & 31,0 & 6,1 \\
\hline 1995 & 769,0 & 50,0 & 51,1 & 6,5 \\
\hline 1996 & 839,7 & 53,3 & 6,8 & 6,4 \\
\hline 1997 & 871,2 & 59,7 & 12,0 & 6,9 \\
\hline 1998 & 843,8 & 57,7 & $-3,4$ & 6,8 \\
\hline 1999 & 586,9 & 49,2 & $-14,7$ & 8,4 \\
\hline 2000 & 644,5 & 55,8 & 13,4 & 8,7 \\
\hline 2001 & 554,0 & 55,6 & $-0,4$ & 10,0 \\
\hline 2002 & 505,9 & 47,2 & $-15,0$ & 9,3 \\
\hline 2003 & 552,2 & 48,3 & 2,2 & 8,7 \\
\hline 2004 & 663,6 & 62,8 & 30,1 & 9,5 \\
\hline 2005 & 881,8 & 73,6 & 17,1 & 8,4 \\
\hline 2006 & $1.089,0$ & 91,3 & 24,1 & 8,4 \\
\hline 2007 & $1.333,6$ & 120,6 & 32,0 & 9,0 \\
\hline 2008 & $1.575,9$ & 173,2 & 43,6 & 11,0 \\
\hline
\end{tabular}

(*) Valores em dólares correntes.

Fonte: SECEX. 
entre vulnerabilidade externa da economia e restrições à capacidade de crescimento autossustentável do país.

Assim sendo, o argumento central deste artigo é que a superação da vulnerabilidade externa - definida por baixo grau de competitividade da economia e, por conseguinte, baixa capacidade de resistência ante a influência de fatores externos desestabilizadores - é condição necessária para a sustentação do crescimento econômico. É importante salientar que essa ideia não negligencia, contudo, a importância de outros fatores que contribuíram para que a economia brasileira tivesse baixíssima taxa média de crescimento ao longo das três últimas décadas, como a crise fiscal e a natureza hiperinflacionária dos anos 1980 e início dos anos 1990.

$\mathrm{O}$ artigo possui três objetivos. Inicialmente, ele analisa as estratégias e os resultados efetivos das políticas comercial e cambial a partir da década de 1980, enfatizando o período pós-Plano Real. Em seguida, busca-se estabelecer uma relação de causalidade dos diferentes graus de vulnerabilidade externa da economia brasileira com o comportamento das taxas de crescimento do PIB do país, entre 1980 e 2008. Por fim, é apresentada uma proposição de política e medidas econô- micas, tais como fiscal, monetária, cambial e industrial e mecanismos de controle de capitais, que, entende-se, tenha condições de equilibrar de forma intertemporal o setor externo e garantir bases para o crescimento econômico sustentável da economia brasileira.

Além desta introdução, o artigo apresenta outras três seções. A segunda seção descreve a lógica das políticas comercial e cambial brasileiras a partir dos anos 1980, analisando seus efeitos em termos de resultados no setor externo e no comportamento das taxas de crescimento do PIB. Para tanto, a análise é realizada em três subperíodos: 1980-1989, 1990-1999 e 1999-2008, ou seja, abrangendo tanto o período de elevada vulnerabilidade externa da economia brasileira até o início dos anos 2000, quanto os anos recentes, pós-2003, de "reversão" da referida vulnerabilidade. Na terceira seção, inicialmente é apresentada uma análise empírica sobre a relação de causalidade entre a vulnerabilidade externa do país e a performance do crescimento econômico ao longo do período sugerido. Em seguida, é mostrada uma proposta de agenda econômica para que o crescimento econômico sustentável da economia brasileira não seja limitado por restrições de balanço de pagamentos. Por 
O que se pode constatar ao final do período é que houve, basicamente, duas "falhas" no processo de formulação das metas do II PND. O primeiro diz respeito ao diagnóstico "otimista" da crise internacional, que levou o governo a optar pela estratégia de desenvolvimento com endividamento externo e que culminou com a deterioração das finanças do setor público, bem como do balanço de pagamentos da segunda metade da década de 1970 em diante. $\mathrm{O}$ segundo erro de previsão estava na crença de que os resultados dos investimentos seriam colhidos no curto prazo, ou seja, houve superestimação do crescimento econômico. fim, na quarta seção, são expostas algumas considerações conclusivas.

\section{2_A dinâmica das políticas comercial e cambial a partir dos anos 1980: da estratégia do ajuste externo à estabilização monetária}

\section{1_0 ajuste externo dos anos 1980}

Ao contrário dos anos 1970, quando as condições de financiamento externo eram de solvência e liquidez, na década de 1980 a economia brasileira passou a ter sérias dificuldades para honrar seus compromissos externos - subentendem-se pagamentos de amortizações e de serviços da dívida externa. Nesse sentido, a articulação da política econômica nos anos 1980 foi caracterizada pelos estímulos ao setor exportador graças, principalmente, às necessidades impostas pelo constrangimento externo.

Após o primeiro choque do petróleo, ocorrido em 1973, o governo brasileiro optou pelo ajuste de oferta como forma de encarar os problemas de vulnerabilidade externa da economia. Para tanto, foi elaborado o II Plano Nacional de Desenvolvimento (PND), que visava sustentar a indução estatal do investi- mento a partir do endividamento externo do país, uma vez que o cenário de liquidez internacional era propício para a absorção de recursos externos. Ademais, para que se consolidassem as aspirações de sustentação do crescimento econômico, faziam-se necessários novos investimentos em capacidade produtiva e infraestrutura. Nesse sentido, segundo Castro e Pires de Souza (1985, p. 37), o II PND acabou tornando-se o primeiro plano de desenvolvimento brasileiro que apresentou uma atenção explícita com a inserção internacional no comércio, estando preocupado tanto em substituir importações como em abrir outras frentes de exportação. ${ }^{3}$

Não é demais ressaltar que o II PND rompeu com o que a Comissão Econômica para a América Latina e o Caribe (CEPAL) denominava de etapa "difícil" do processo de substituição de importações, integrando o parque industrial brasileiro, com a consolidação de uma indústria de bens intermediários e de capital. Adicionalmente, houve avanço significativo na infraestrutura do país, em especial no que diz respeito à energia e às telecomunicações. $\mathrm{O}$ avanço estrutural ocorreu até com elevadas taxas de crescimento, superiores a 7,0\% ao ano, durante o período 1974-1980. 
No início dos anos 1980, em decorrência principalmente dos choques externos protagonizados pela elevação dos juros internacionais, em 1979, do preço do petróleo, entre 1979 e 1980, e pelo desaquecimento do PIB mundial, a economia brasileira passou a apresentar sérios problemas de balanço de pagamentos, cuja consequência foi, na ausência de uma sistemática de financiamento externo, a crise da dívida externa.

Naquela ocasião, em contraste com a opção de ajustamento realizada no II PND e, de certa forma, condicionada por ela, a política econômica implementada foi centrada no ajustamento externo emergencial. Para tanto, duas foram as estratégias adotadas: por um lado, a recessão da economia passou a ser a resposta à ruptura do padrão de financiamento externo, visto que o ajuste recessivo de curto prazo propiciava um excedente exportável, o que acabou reduzindo os desequilíbrios da balança comercial. Nesse sentido, as políticas fiscal e monetária restritivas encarregaram-se de arrefecer a atividade econômica. Por outro, políticas de maxidesvalorizações cambiais passaram a ser imprescindíveis para expandir as exportações e contrair, ainda mais, as importações. É importan- te ressaltar que, em um contexto de inflação elevada e de política de arrocho salarial, os saldos comerciais foram estimulados, uma vez que a relação câmbio/ salário elevou-se consideravelmente. A recessão no período 1981-1983, aliada:

i. à maturação dos investimentos produtivos realizados durante o II PND, ${ }^{4}$ que permitiram maior redução das importações e a ampliação das exportações;

ii. às políticas de promoção das exportações e de controle de importações; e

iii. à recuperação da economia mundial após 1984,

acabou contribuindo para reverter o resultado da balança comercial, e, com isso, os problemas de ajustamento externo foram mitigados. Tendo como referência o Gráfico 1, constata-se que, entre 1980 e 1989, as exportações cresceram, em média, 9,6\% ao ano, saltando de US\$ 20,1 bilhões, em 1980, para US\$ 34,4 bilhões, em 1989, enquanto as importações decresceram, em média, 1,6\% ao ano. Como consequência, ao longo do referido período, o saldo acumulado da balança comercial atingiu o montante de US\$ 86,1 bilhões.
${ }_{4}$ Tão importantes quanto os resultados em termos quantitativos dos esforços de investimentos realizados durante o II PND são os resultados em termos de mudança estrutural da pauta de exportações, com ganhos significativos de participação dos produtos manufaturados na pauta, em detrimento dos produtos primários, em parte refletindo o fato de que ao final desse período "em marcha forçada, a economia subiria a rampa das indústrias capital-intensivas $e$ tecnológico-intensivas" (Castro e Pires de Souza, 1985, p. 76). A Tabela 5 apresenta a pauta das exportações brasileiras em anos selecionados.

5 A taxa de crescimento média do PIB mundial entre 1984-1989 foi de 4,0\% ao ano, contra $1,9 \%$ ao ano no período 1980-1983. As importações mundiais anuais médias entre 1984-1989 foram cerca de $25,0 \%$ maiores do que no período 1980-1983, segundo dados do Fundo Monetário Internacional divulgados pela Secretaria de Comércio Exterior (SECEX). 


\section{Gráfico 1_ Exportações e importações (US\$ bilhões), 1980-2008}

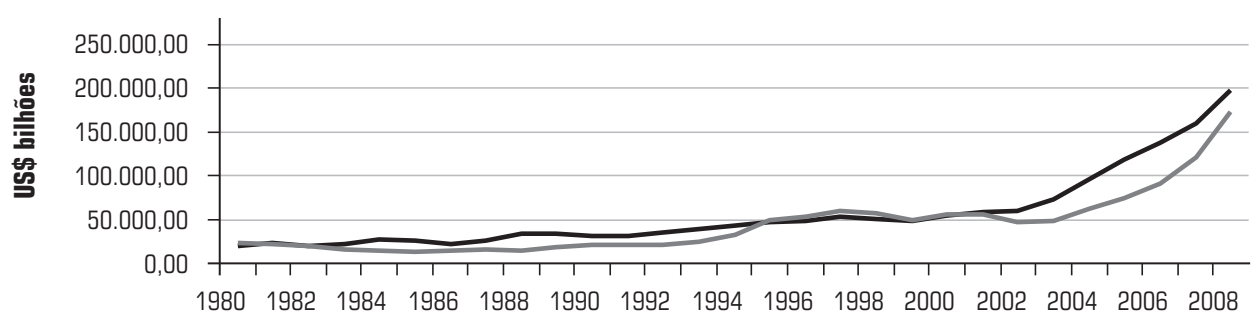

Ano

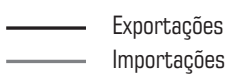

Fonte: Tabela 2 e Tabela 3

Tabela 4 _ Balanço de pagamentos em transações correntes, US\$ bilhões

\begin{tabular}{|c|c|c|c|}
\hline Ano & Saldo & Ano & Saldo \\
\hline 1980 & $-12,7$ & 1995 & $-18,45$ \\
\hline 1981 & $-11,7$ & 1996 & $-23,5$ \\
\hline 1982 & $-16,3$ & 1997 & $-30,4$ \\
\hline 1983 & $-6,8$ & 1998 & $-33,4$ \\
\hline 1984 & 0,1 & 1999 & $-25,3$ \\
\hline 1985 & $-0,2$ & 2000 & $-24,2$ \\
\hline 1986 & $-5,3$ & 2001 & $-23,2$ \\
\hline 1987 & $-1,4$ & 2002 & $-7,6$ \\
\hline 1988 & 4,2 & 2003 & 4,2 \\
\hline 1989 & 1,0 & 2004 & 11,7 \\
\hline 1990 & $-3,8$ & 2005 & 14,0 \\
\hline 1991 & $-1,4$ & 2006 & 13,6 \\
\hline 1992 & 6,1 & 2007 & 1,5 \\
\hline 1993 & $-0,7$ & 2008 & $-28,3$ \\
\hline 1994 & $-1,8$ & - & - \\
\hline
\end{tabular}

Fonte: Banco Central do Brasil. 
Tabela 5_Composição das exportações, em US\$ bilhões, para anos selecionados

\begin{tabular}{|c|c|c|c|c|c|c|}
\hline Ano & $\begin{array}{l}\text { Produtos } \\
\text { básicos }\end{array}$ & $\begin{array}{c}\text { Produtos } \\
\text { industrializados } \\
\text { (1) }+ \text { (2) }\end{array}$ & $\begin{array}{c}\text { Produtos semi- } \\
\text { manufaturados } \\
\text { (1) }\end{array}$ & $\begin{array}{c}\text { Produtos } \\
\text { manufaturados } \\
\text { (2) }\end{array}$ & Outros & Total \\
\hline 1980 & $8.488,0$ & $11.376,0$ & $2.349,0$ & $9.027,0$ & 268,0 & $20.132,0$ \\
\hline 1985 & $8.538,0$ & $16.821,0$ & $2.758,0$ & $14.063,0$ & 280,0 & $25.639,0$ \\
\hline 1990 & $8.746,0$ & $22.119,0$ & $5.108,0$ & $17.011,0$ & 549,0 & $31.414,0$ \\
\hline 1995 & $10.969,0$ & $34.711,0$ & $9.146,0$ & $25.565,0$ & 826,0 & $46.506,0$ \\
\hline 2000 & $12.561,0$ & $41.027,0$ & $8.499,0$ & $32.559,0$ & $1.498,0$ & $55.086,0$ \\
\hline 2004 & $28.520,0$ & $66.373,0$ & $13.433,0$ & $53.137,0$ & $1.582,0$ & $96.475,0$ \\
\hline 2008 & $73.029,0$ & $119.756,0$ & $27.073,0$ & $92.683,0$ & $5.157,0$ & $197.942,0$ \\
\hline
\end{tabular}

Fonte: IPEADATA.

A análise do gráfico mostra que: em primeiro lugar, os superávits comerciais obtidos ao longo da década de 1980 decorreram tanto do crescimento das exportações - o volume total das exportações, em 1989, foi $71,1 \%$ superior às exportações de 1980 - quanto da queda acentuada das importações - as importações, entre 1980 e 1989, caíram 20,5\%. Em relação ao PIB, a participação das exportações, entre 1980 e 1989, permaneceu relativamente estável - 8,1\% do PIB em 1980 e 7,9\% do PIB em 1989 -, ao passo que a razão importações/PIB caiu de 9,2\%, em 1980, para 4,2\%, em 1989. Em segundo lugar, percebe-se que, após a crise da dívida externa no início dos anos 1980, a economia brasileira passou a obter recorrentes superávits na balança comercial, que perduraram até 1994. Em suma, tais considerações corroboram o argumento de que o ajuste externo dos anos 1980 ocorreu em razão do aumento das exportações e do processo de controle de importações, caracterizado, em grande parte, pelo desaquecimento da atividade econômica e pela redução estrutural da necessidade de importação de bens de capital e de bens intermediários.

Centrando a atenção na política de promoção das exportações, pelo menos dois fatores internos explicam o dinamismo das exportações brasileiras ao longo dos anos 1980, quais sejam:

i. a adoção da política de minidesvalorização cambial, implementada após as maxidesvalorizações cambiais de 
$\because$ Considera-se como Plano Real o período julho/1994janeiro/1999 devido ao fato de que somente ao longo desse período as políticas cambial e monetária foram operacionalizadas de forma a atingirem seus objetivos, quais sejam: a política cambial objetivava o controle dos preços, ao passo que a política monetária objetivava o equilíbrio do balanço de pagamentos, através da captação de "poupança externa", via capital de portfólio.
1981 e 1983, foi importante para manter a taxa de câmbio efetiva real relativamente estável, principalmente em um contexto de inflação crescente;

ii. os incentivos para dinamizar as exportações tradicionais.

No que diz respeito especificamente ao primeiro fator, o Gráfico 2 apresenta a evolução da taxa de câmbio efetiva real, entre 1980 e 2008.

Como se observa no Gráfico 2, nos primeiros anos da década de 1980, a taxa de câmbio apresentou trajetória de- clinante. Entre meados de 1983 e 1985, houve desvalorização do câmbio, medida que veio a fortalecer os incentivos ao setor exportador. Após ligeira estabilidade até 1987, ao final do período a taxa de câmbio voltou a se valorizar. Por ocasião do Plano Real, julho/1994 a janeiro/1999, ${ }^{6}$ o câmbio valorizou-se consideravelmente. Depois da introdução do regime de flexibilidade cambial, em janeiro de 1999, a trajetória do câmbio apresentou duas dinâmicas distintas: no período 19992002, a taxa de câmbio efetiva real desvalorizou-se de forma acentuada, à medida que, a partir de 2003, ela passou a valori-

\section{Gráfico 2_Taxa de câmbio efetiva real (IPA-0G*), Índice 2000 (média) = 100}

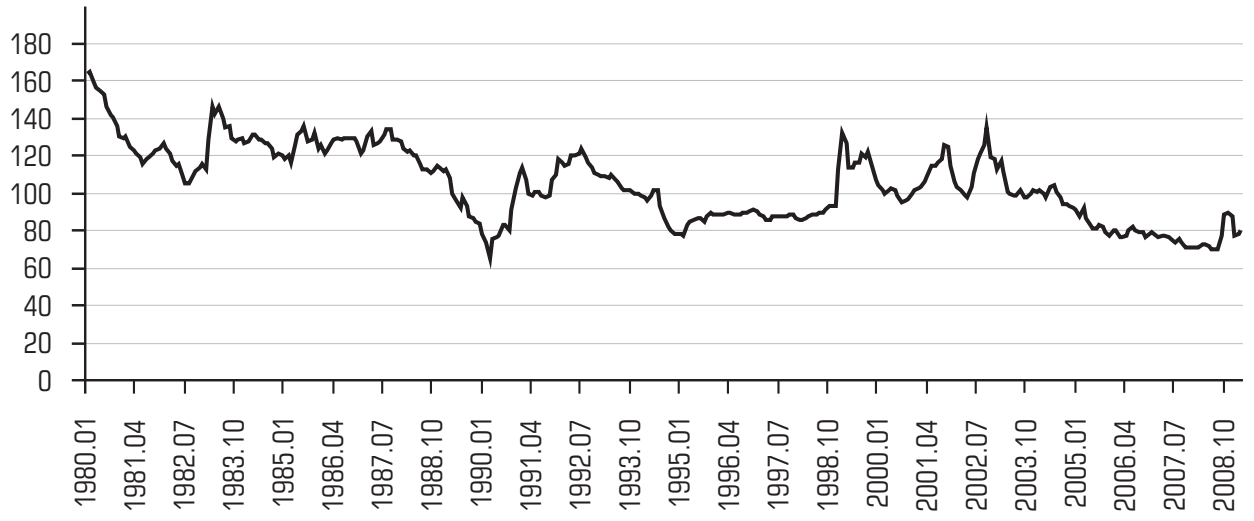

(*) IPA-OG = Índice de preços do atacado por grupos de produtos agrícolas e classes e gêneros da indústria de transformação. Considera, além da variação de preços no Brasil, a variação de preço dos produtos exportados.

Fonte: IPEADATA 
zar-se recorrentemente. ${ }^{7}$ Portanto, verifica-se que a época foi marcada por significativa oscilação cambial.

\section{2_ As políticas de liberalização comercial e apreciação cambial dos anos 1990 e o recrudescimento da vulnerabilidade externa no período do Plano Real}

Nos anos 1990, as políticas econômicas dos governos Fernando Collor, Itamar Franco e Fernando Henrique Cardoso foram centradas na estabilização monetária e na consolidação das reformas neoliberais. Apesar de as estratégias antiinflacionárias terem sido relativamente distintas nos referidos governos - no governo Fernando Collor, a política econômica foi norteada pelas restrições fiscal e, principalmente, monetária, enquanto, nos governos Itamar Franco e Fernando Henrique Cardoso, ao longo de seu primeiro mandato, 1995-1998, além das austeridades fiscal e monetária, a apreciação cambial foi fundamental para os objetivos de controle inflacionário - a mudança de paradigma na condução da economia, via liberalização comercial e financeira, ${ }^{8}$ foi o elo comum das estratégias econômicas dos referidos governos e acabou se tornando essencial para caracterizar a lógica de inserção internacional do país no mundo globalizado.

A ideia básica que norteou a política de liberalização comercial nos referidos governos foi a de que

\begin{tabular}{|c|c|c|c|}
\hline $\begin{array}{l}7 \text { A volatilidade cambial ao } \\
\text { longo do período pós-Plano } \\
\text { Real pode ser explicada } \\
\text { como se segue: em 1999, a } \\
\text { política de bandas cambiais } \\
\text { e o histórico de crises em } \\
\text { economias similares ao Brasil } \\
\text { propiciaram a bancarrota do } \\
\text { regime cambial brasileiro e } \\
\text { a desvalorização acentuada } \\
\text { do real; em 2002, graças à } \\
\text { apreensão dos investidores } \\
\text { nacionais e internacionais } \\
\text { com os rumos da sucessão } \\
\text { presidencial no Brasil, à } \\
\text { crise cambial e financeira da }\end{array}$ & $\begin{array}{l}\text { Argentina e à “deflação” do } \\
\text { Índice Nasdaq, ocorreu um } \\
\text { ataque especulativo contra o } \\
\text { real que acabou ocasionando } \\
\text { uma desvalorização da moeda } \\
\text { brasileira da ordem de } 60,0 \% \text {, } \\
\text { ao longo dos nove primeiros } \\
\text { meses do ano; e, por fim, a } \\
\text { partir de } 2003 \text {, a austeridade } \\
\text { monetária, em grande parte } \\
\text { para assegurar o cumprimento } \\
\text { das metas de inflação, induziu } \\
\text { a valorização cambial, o que } \\
\text { ainda foi intensificada pela } \\
\text { alta dos preços das commodities } \\
\text { que o Brasil exportava, }\end{array}$ & $\begin{array}{l}\text { aumentando, assim, os saldos } \\
\text { comerciais. } \\
{ }^{8} \text { Além das medidas } \\
\text { relacionadas diretamente ao } \\
\text { setor externo, outras mudanças } \\
\text { no paradigma econômico } \\
\text { relacionadas ao papel do setor } \\
\text { público, mormente sob os } \\
\text { auspícios das privatizações } \\
\text { e desregulamentações que } \\
\text { caracterizam esse período, } \\
\text { relacionaram-se indiretamente } \\
\text { com a nova forma de } \\
\text { inserção da economia no } \\
\text { exterior, principalmente } \\
\text { através da potencial atração }\end{array}$ & $\begin{array}{l}\text { de investimentos diretos } \\
\text { estrangeiros. Neste caso, a } \\
\text { entrada de investimentos } \\
\text { diretos prioritariamente para } \\
\text { o setor de serviços, em sua } \\
\text { maioria não comercializáveis, } \\
\text { e na forma de fusões e } \\
\text { aquisições, contrasta com } \\
\text { a entrada de investimentos } \\
\text { industriais na forma de } \\
\text { green field característicos das } \\
\text { décadas antecedentes. }\end{array}$ \\
\hline
\end{tabular}


[a] reduction in world barriers to trade could accelerate growth, provide stimulus to new forms of productivity-enhancing specialization, and lead to a more rapid pace of job creation and poverty reduction around the world (World Bank, 2002, p. 11).

Em suma, o estímulo às exportações deveria ser substituído por ganhos de produtividade ("desenvolvimento") e abertura às importações ("estabilização").

Infelizmente, contudo, os efeitos dessa estratégia econômica não contribuíram para dinamizar tanto o crescimento econômico (Tabela 1) quanto o grau de abertura da economia brasileira, como mostra o Gráfico 3.

Observa-se que o grau de abertura da economia brasileira, ao longo dos anos 1990, manteve-se relativamente estável. Ademais, comparativamente aos anos 1980 - quando as relações exportações/PIB e importações/PIB apresentaram médias anuais de 9,5\% e 6,4\%, respectivamente -, os anos 1990 mostram que a média anual da razão exportações/PIB caiu para 7,6\%, ao passo que a relação importações/PIB elevou-se somente $0,1 \%$, apresentando uma média anual de 6,5\%.

Outro aspecto importante a registrar, tendo como referência o Gráfico 3, é que, apesar de as primeiras iniciativas de abertura comercial datarem do final da década de 1980 e começo da década de 1990, o grau de abertura da economia somente foi alterado de forma mais acentuada a partir do final dos anos 1990, sobretudo via aumento das exportações, e, em 2003, a economia brasileira já apresentava um grau de abertura superior ao dos anos 1980.

\section{Gráfico 3_Grau de abertura da economia (exportação + importação / PIB), 1980-2008}

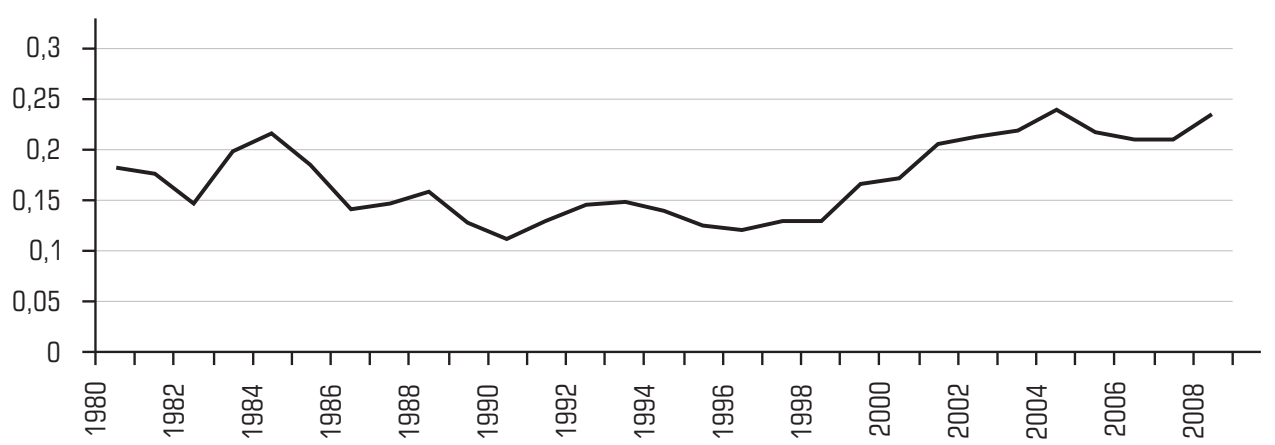

Fonte: Tabela 1, Tabela 2 e Tabela 3. 
A gestão Fernando Collor foi o starting dessa estratégia de política econômica: entre 1990 e 1992, a política comercial caracterizou-se por um processo de liberalização comercial, cuja essência foi a redução e/ou eliminação das barreiras alfandegárias em relação às importações e a extinção dos incentivos fiscais às exportações. Tal política comercial, denominada, segundo Veiga (2002), "política unilateral de liberalização comercial", fez com que a balança comercial acumulasse um superávit ao redor de US\$ 36,6 bilhões (Gráfico 1) no breve mandato de Fernando Collor.

A partir do final do governo Itamar Franco e dos governos Fernando Henrique Cardoso, essencialmente em seu primeiro mandato, ocorreram transformações substanciais no desempenho da balança comercial, uma vez que a política econômica dos referidos governos foi centrada na relativa "fixação" da taxa de câmbio nominal e na elevação das taxas de juros, e na aceleração da abertura comercial, iniciada no governo Fernando Collor. As consequências das aberturas comercial e financeira, aliadas à sobrevalorização cambial, acabaram resultando, na segunda metade da década de 1990, em armadilhas e restrições que impediram o crescimento econômico do país.
Como se sabe, via de regra, programas de estabilização econômica baseados em âncora cambial e liberalização comercial e financeira têm mostrado que, no primeiro momento, há uma queda abrupta da taxa de inflação acompanhada por uma apreciação substancial da taxa de câmbio. ${ }^{9}$ A taxa real de câmbio aprecia-se como resultado da diferença entre a taxa de inflação doméstica e a taxa de inflação internacional em um contexto no qual a taxa nominal de câmbio mantém-se relativamente estável, resultando em déficits no balanço de pagamentos em transações correntes. Normalmente, esses déficits são acompanhados pela entrada de capital, não somente para financiar os referidos déficits, mas também para estabilizar o volume das reservas internacionais.

Se por um lado o Plano Real obteve relativo sucesso no que diz respeito ao controle do processo inflacionário, por outro o incentivo às importações, em razão da abertura comercial e da valorização cambial, e o ritmo lento das exportações ocasionaram rápida deterioração da balança comercial: entre 1990 e 1994, o saldo acumulado da balança comercial foi da ordem de US\$ 64,0 bilhões, enquanto, no período 1995-1998, a balança comercial acumulou um défi-
$9 \quad$ Uma dependência por fluxos de capitais internacionais causa, entre outros problemas, a apreciação da taxa real de câmbio. Assim sendo, na ausência de outros mecanismos compensatórios, o crescimento dos desequilíbrios comerciais acaba deixando o país em uma situação de crescente vulnerabilidade externa. 
${ }_{10}$ Prates (2005) destaca que essa assimetria ocorre nas esferas monetárias e financeiras de natureza centro-periferia, e que esta se tornou mais perversa por causa do perfil mais volátil e especulativo dos fluxos de capitais com o processo de globalização financeira.

11 De acordo com Gonçalves (2005), no período de 19952002, $57,9 \%$ do ingresso de IDE foi na forma de aquisição e fusão, e entre 1996-2002 as privatizações absorveram 20,0\% do ingresso de IDE. cit ao redor de US\$22,4 bilhões (Gráfico 1). Adicionando-se ao déficit acumulado nesse período os pagamentos de juros e o aumento das remessas de lucros e dividendos, a economia brasileira passou a apresentar recorrentes e significativos déficits no balanço de pagamentos em transações correntes: entre 1994 e 1998, o déficit em transações correntes atingiu um montante de US\$107,5 bilhões, como mostra a Tabela 4.

Por sua vez, os referidos déficits passaram a ser financiados pelo ingresso de capital externo, seja de investimento de risco, seja, predominantemente, de portfólio, o que acabou provocando a elevação do passivo externo do país. Cabe ressaltar que, conforme Prates (2005), a maior vulnerabilidade externa dos países em desenvolvimento, nos anos 1990, decorreu sobretudo do caráter assimétrico do sistema monetário e financeiro internacional. ${ }^{10}$ Nesse sentido, por um lado, os países em desenvolvimento seriam mais afetados pela volatilidade inerente aos fluxos recentes de capitais, uma vez que o volume e a direção desses fluxos são determinados principalmente por uma dinâmica exógena a esses países, a saber: o ciclo econômico e a política monetária dos países centrais e as decisões de aplicação e resgate dos investidores globais. Por outro, o raio de manobra dos países em desenvolvimento para adotar políticas anticíclicas teria se tornado menor, o que dificulta a redução da vulnerabilidade diante da reversão desses fluxos e das crises financeiras recentes.

Segundo Gonçalves (2005), a participação do ingresso de investimento direto estrangeiro (IDE) com forte predominância no setor de serviços em detrimento do setor industrial (com destaque para os setores de telecomunicações, intermediação financeira e comércio), associada principalmente ao processo de desregulamentação e privatização da segunda metade da década de 1990, contribuiu para aumentar o caráter de vulnerabilidade externa da economia brasileira. $^{11}$

Em relação aos capitais de portfólio, cabe ressaltar que eles ingressaram no mercado doméstico atraídos pelo elevado diferencial de juros, instrumento utilizado no âmbito do arcabouço da política macroeconômica de estabilização monetária do período.

A inconsistência intertemporal dessa estratégia acabou provocando inúmeros ataques especulativos ao real ao longo da segunda metade dos anos 1990, diga-se de passagem, quase todos decor- 
rentes de um mix de "crise de contágio" e de evidência dos desequilíbrios macroeconômicos da economia brasileira, ${ }^{12} \mathrm{em}$ especial o externo, a ponto até mesmo de acentuar o grau de vulnerabilidade e fragilidade externa do país. Nesse particular, Paula e Alves Jr. (1999) desenvolveram um Índice de Fragilidade Externa ${ }^{13}$ para avaliar a capacidade de pagamento sobre as obrigações virtuais e reais em moeda estrangeira do Brasil, entre os anos 1992 e 1997. De acordo com os autores, o referido Índice manteve-se estável entre 1992 e 1994, ao passo que, a partir do início do Plano Real, se elevou consideravelmente - um comportamento que se mostrou negativamente correlacionado com o resultado da balança comercial no mesmo período, conforme observado no Gráfico 1.

\section{3_ Da restrição externa gerada pelo Plano Real à reversão dos anos 2000}

No início de 1999, quando a estratégia de financiamento do déficit externo crônico esgotou-se e o grau de confiança dos agentes econômicos na política econômica deixou de existir, não houve alternativa a não ser a mudança do regime monetário-cambial, substituição da banda cambial por uma taxa de câmbio flexível e implementação do sistema de metas de inflação, o que acabou determi- nando o fim do modelo de estabilização monetária até então adotado. ${ }^{14}$

A despeito do receio das autoridades econômicas acerca do desempenho da economia brasileira, sobretudo no que diz respeito à inflação quando da mudança dos parâmetros que regiam a política macroeconômica durante o Plano Real, em 1999, o PIB, surpreendentemente, apresentou resultado ligeiramente positivo $(0,3 \%)$, e a inflação ficou muito abaixo das previsões iniciais que sinalizavam inflação de dois dígitos - o IPCA, inflação oficial, fechou o ano em 8,94\%. Ademais, em 2000, o PIB cresceu 4,3\%, e o processo inflacionário foi arrefecido
${ }^{14}$ Entre 1994 e 1998, a política econômica foi articulada de forma tal que a taxa de câmbio era responsável pela administração dos preços, e a taxa de juros tinha a responsabilidade de equilibrar o balanço de pagamentos, via conta capital. A partir de 1999 , a lógica da política econômica foi invertida: o câmbio passou a ser responsável pelo equilíbrio do balanço de pagamentos, e a taxa de juros passou a monitorar o sistema de metas de inflação. Também foram adotadas, a partir desse ano, metas fiscais. 
consideravelmente, com o IPCA fechando o ano em 5,97\%.

Se por um lado o overshooting cambial não causou efeito pass-through, a desvalorização cambial, por outro, contribuiu para uma significativa redução no déficit da balança comercial tanto em 1999 quanto em 2000: em 1998, o país teve um déficit comercial de cerca de US\$ 6,5 bilhões, enquanto, em 1999 e 2000, a balança comercial apresentou déficits da ordem de US\$1,2 bilhão e US\$ 0,7 bilhão, respectivamente.

Os anos 2001 e 2002 foram de baixo crescimento econômico em nível mundial e apresentaram-se particularmente desfavoráveis para a economia brasileira, principalmente por causa dos seguintes fatores: crise energética no Brasil; crise cambial da Argentina, que ocasionou um risco de "contágio"; ocorrência dos atentados terroristas às "torres gêmeas" (Estados Unidos) e turbulência nos mercados financeiros internacionais, com crise nas Bolsas de Wall Street e Nasdaq. Esses fatores, mais o contexto de elevada aversão dos capitais internacionais ao risco dos países emergentes e a questão da sucessão presidencial, que acabou implicando a elevação da percepção de risco dos títulos brasileiros, fizeram com que o Brasil enfrentasse uma crise con- juntural-cambial, condicionando, assim, o desempenho da economia em 2002.

A crise acabou pressionando a taxa de câmbio, que se elevou de um patamar médio de R\$2,32 em março de 2002 para $\mathrm{R} \$ 3,89$ em setembro do mesmo ano, ou seja, desvalorização da ordem de 67,0\%. Como consequência, houve reflexos na inflação e nos fluxos cambiais, com saídas substanciais de capitais estrangeiros do país. Na ocasião, as autoridades econômicas procuraram conter a saída de capitais, elevando a taxa básica de juros (Selic) de 18,0\% ao ano, em julho de 2002, para 25,0\%, em dezembro do mesmo ano, chegando a $26,5 \%$ em fevereiro de 2003.

Após o pico de desvalorização cambial, influenciado pelo elevado diferencial de juros, o câmbio seguiu uma tendência de revalorização, acentuada posteriormente com a significativa melhora da balança comercial e do resultado do balanço de pagamentos. A apreciação cambial, todavia, não impediu a continuidade do crescimento vigoroso das exportações, as quais foram impulsionadas pelo aumento no preço dos produtos de exportação brasileiros, em especial as commodities agrícolas e minerais, pela recuperação de mercados retraídos (mormente Argentina e Estados 
Unidos), pelo aumento de penetração em novos mercados e pelo período de aquecimento da economia e do comércio mundiais. Como consequência, o saldo da balança comercial em 2002 foi quase cinco vezes maior do que no ano anterior (US\$13,1 bilhões contra US\$2,6 bilhões) (Gráfico 1).

A partir de 2003, os resultados da balança comercial passam a ser condicionados tanto pelas exportações, que cresceram a uma taxa média de $22,0 \%$ ao ano no período 2003-2008, quanto pelas importações, que cresceram acima das exportações, o que pode ser verificado pela inflexão da curva do Gráfico 1. Tal movimento era de certa forma esperado, em razão da aparente retomada de um crescimento estável do PIB e da tendência de apreciação cambial.

O saldo no balanço de pagamentos em transações correntes apresentou, a partir de 2003, sucessivos superávits, revertendo a tendência do longo período de saldos deficitários: entre 1995 e 1999, o déficit acumulado em transações correntes chegou a US\$131,1 bilhões, enquanto, entre 2003 e 2007, o saldo acumulado em transações correntes foi superavitário em US\$ 45,0 bilhões (Tabela 4). Em decorrência desses bons resultados, as reservas internacionais mantiveram-se próximas a 10,0\% do PIB, em média, entre 2003 e 2008, chegando a acumular mais de US $\$ 190,0$ bilhões em 2008, contra uma média de 6,0\% do PIB no período entre 1994 e 2002.

Considerando-se ainda a significativa melhora de outros indicadores macroeconômicos, como a relação dívida total/PIB e o serviço da dívida/exportações (Tabela 8), verifica-se que, entre 2004 e 2008, por um lado, o comportamento auspicioso do setor externo reduziu a vulnerabilidade externa do país, que, desde o início do Plano Real, era bastante elevada. Por outro, as taxas de crescimento econômico, depois de se apresentarem relativamente baixas e voláteis entre 1999 e 2003, cresceram mais dinamicamente, após 2004.

Entretanto, pelo menos três importantes observações devem ser feitas sobre a dinâmica do setor externo da economia brasileira no período recente:

i. algumas análises têm ressaltado a fragilidade exportadora brasileira a partir do processo de "reprimarização" da pauta de exportação, ${ }^{15}$ ou seja, o aumento da presença dos produtos primários, intensivos em recursos naturais (conforme mostra a Tabela 6);
15 Veja, para tanto, Gonçalves (2005) e Baumann (2002). 
Tabela 6_Exportações por fator agregado, média do período em \%

\begin{tabular}{|c|c|c|c|}
\hline Período & $\begin{array}{c}\text { Produtos básicos } \\
\text { (\%) }\end{array}$ & $\begin{array}{c}\text { Produtos } \\
\text { semimanufaturados } \\
(\%)\end{array}$ & $\begin{array}{c}\text { Produtos } \\
\text { manufaturados } \\
\text { (\%) }\end{array}$ \\
\hline 1990-1993 & 26,5 & 15,8 & 57,7 \\
\hline 1994-1998 & 25,9 & 17,6 & 56,5 \\
\hline 1999-2002 & 26,1 & 16,2 & 57,7 \\
\hline 2003-2008 & 32,0 & 14,0 & 54,0 \\
\hline
\end{tabular}

Fonte: SECEX

\section{Tabela 7_Reservas cambiais, US\$ milhões}

\begin{tabular}{|c|c|}
\hline Ano & Valor \\
\hline 1990 & $9.973,0$ \\
\hline 1991 & $9.406,0$ \\
\hline 1992 & $23.754,0$ \\
\hline 1993 & $32.211,0$ \\
\hline 1994 & $38.806,0$ \\
\hline 1995 & $51.840,0$ \\
\hline 1996 & $60.110,0$ \\
\hline 1997 & $52.173,0$ \\
\hline 1998 & $44.556,0$ \\
\hline 1999 & $36.342,0$ \\
\hline 2000 & $33.011,0$ \\
\hline 2001 & $35.866,0$ \\
\hline 2002 & $37.823,0$ \\
\hline 2003 & $49.296,0$ \\
\hline 2004 & $52.935,0$ \\
\hline 2005 & $53.799,0$ \\
\hline 2006 & $85.839,0$ \\
\hline 2007 & $180.334,0$ \\
\hline 2008 & $193.783,0$ \\
\hline
\end{tabular}

(*) Valores em final de período.

Fonte: Banco Central do Brasil. ii. em termos da importância do setor externo na economia brasileira, dadas as perspectivas do processo de abertura e o aprofundamento das relações brasileiras com o exterior, verifica-se que a participação da corrente de comércio no PIB aumentou de 16,7\%, média dos anos 1980, para mais de 22,0\%, média entre 2003-2008, representando ganhos de importância tanto do lado das exportações quanto do das importações; e

iii. o Brasil perdeu participação relativa no comércio internacional quando comparado com os anos 1980 (média de 1,2\% nos anos 1980 contra $0,97 \%$ no período pós-abertura, 1990-2008), ${ }^{16}$ segundo dados da Secretaria de Comércio Exterior (SECEX). somente os anos pós-

desvalorização de 2002, esse valor é de $1,04 \%$. 
Tabela 8_ Indicadores de vulnerabilidade externa do Brasil, endividamento e liquidez, 1980-2008

\begin{tabular}{|c|c|c|c|c|c|c|c|c|}
\hline Ano & $\begin{array}{c}\text { Dívida total } \\
\text { /PIB (\%) }\end{array}$ & $\begin{array}{c}\text { Dívida } \\
\text { externa } \\
\text { curto prazo/ } \\
\text { exportações } \\
(\%)\end{array}$ & $\begin{array}{c}\text { Serviço da } \\
\text { dívida/ } \\
\text { exportações } \\
(\%)\end{array}$ & $\begin{array}{c}\text { Serviço da } \\
\text { dívida/PIB } \\
\text { (\%) }\end{array}$ & $\begin{array}{c}\text { Juros/ } \\
\text { exportações } \\
\text { (\%) }\end{array}$ & $\begin{array}{c}\text { Reservas } \\
\text { (liquidez)/ } \\
\text { dívida total } \\
(\%)\end{array}$ & $\begin{array}{l}\text { Dívida total/ } \\
\text { exportações } \\
\text { (Razão) }\end{array}$ & $\begin{array}{c}\text { Reservas } \\
\text { (liquidez)/ } \\
\text { serviço da } \\
\text { dúvida } \\
\text { (Razão) }\end{array}$ \\
\hline 1980 & 27,0 & 51,7 & 70,9 & 6,0 & 37,0 & 10,8 & 3,2 & 0,5 \\
\hline 1981 & 28,6 & 53,9 & 78,1 & 7,0 & 44,2 & 10,1 & 3,2 & 0,4 \\
\hline 1982 & 31,5 & 75,8 & 101,9 & 7,6 & 60,0 & 4,7 & 4,2 & 0,2 \\
\hline 1983 & 49,5 & 56,7 & 60,7 & 7,0 & 45,9 & 4,9 & 4,3 & 0,3 \\
\hline 1984 & 53,8 & 40,9 & 54,6 & 7,8 & 41,7 & 11,7 & 3,8 & 0,8 \\
\hline 1985 & 49,8 & 36,3 & 58,2 & 7,1 & 43,2 & 11,0 & 4,1 & 0,8 \\
\hline 1986 & 43,1 & 42,3 & 66,5 & 5,8 & 45,1 & 6,1 & 5,0 & 0,5 \\
\hline 1987 & 42,9 & 52,1 & 56,2 & 5,2 & 35,0 & 6,2 & 4,6 & 0,5 \\
\hline 1988 & 37,1 & 32,4 & 66,4 & 7,3 & 31,0 & 8,1 & 3,4 & 0,4 \\
\hline 1989 & 27,8 & 47,2 & 57,3 & 4,7 & 31,6 & 8,4 & 3,4 & 0,5 \\
\hline 1990 & 26,3 & 85,6 & 65,1 & 4,4 & 34,1 & 8,1 & 3,9 & 0,5 \\
\hline 1991 & 30,5 & 97,8 & 56,1 & 4,4 & 29,6 & 7,6 & 3,9 & 0,5 \\
\hline 1992 & 35,1 & 70,2 & 47,7 & 4,4 & 22,6 & 17,5 & 3,8 & 1,4 \\
\hline 1993 & 32,2 & 81,6 & 47,4 & 4,2 & 20,9 & 23,3 & 3,6 & 1,8 \\
\hline 1994 & 26,3 & 65,7 & 38,2 & 3,1 & 13,3 & 27,1 & 3,3 & 2,3 \\
\hline 1995 & 19,9 & 65,6 & 44,5 & 2,7 & 21,6 & 33,9 & 3,3 & 2,5 \\
\hline 1996 & 20,6 & 79,1 & 54,7 & 3,1 & 25,1 & 34,7 & 3,6 & 2,3 \\
\hline 1997 & 22,0 & 69,3 & 72,6 & 4,4 & 24,3 & 27,2 & 3,6 & 1,4 \\
\hline 1998 & 26,5 & 51,7 & 87,4 & 5,3 & 28,4 & 19,9 & 4,4 & 1,0 \\
\hline 1999 & 38,4 & 57,1 & 126,5 & 10,4 & 33,7 & 16,1 & 4,7 & 0,6 \\
\hline 2000 & 33,6 & 54,4 & 88,6 & 7,6 & 29,0 & 15,2 & 3,9 & 0,7 \\
\hline 2001 & 37,9 & 47,5 & 84,9 & 8,9 & 28,0 & 17,1 & 3,6 & 0,7 \\
\hline 2002 & 41,8 & 38,8 & 82,7 & 9,9 & 23,6 & 18,0 & 3,5 & 0,8 \\
\hline 2003 & 38,8 & 27,6 & 72,5 & 9,6 & 19,4 & 22,9 & 2,9 & 0,9 \\
\hline 2004 & 30,3 & 19,4 & 53,7 & 7,8 & 14,8 & 26,3 & 2,1 & 1,0 \\
\hline 2005 & 19,2 & 15,9 & 55,8 & 7,5 & 12,2 & 31,7 & 1,4 & 0,8 \\
\hline 2006 & 15,9 & 14,7 & 41,3 & 5,2 & 10,8 & 49,7 & 1,3 & 1,5 \\
\hline 2007 & 14,1 & 24,2 & 32,4 & 3,8 & 9,5 & 93,3 & 1,2 & 3,5 \\
\hline 2008 & 12,1 & 18,4 & 19,0 & 2,3 & 7,9 & 97,7 & 1,0 & 5,1 \\
\hline
\end{tabular}

Fonte: Banco Central do Brasil. 


\section{3_Vulnerabilidade externa "versus" crescimento econômico: o que fazer?}

Como foi visto na Seção 2, a política macroeconômica dos anos 1980, em geral, foi articulada no sentido de mitigar a vulnerabilidade externa da economia pelo lado do comércio, através da recessão econômica do início dos anos 1980, das desvalorizações cambiais e dos incentivos à exportação na segunda metade da década. Ademais, a estratégia adotada nos anos 1980 contou tanto com a redução da necessidade de importação quanto com mudanças estruturais importantes na organização produtiva do país, decorrentes sobretudo dos investimentos relacionados ao II PND, a partir da segunda metade da década de 1970.

A despeito dos excelentes resultados da balança comercial no referido período, basicamente do bom desempenho exportador, graças principalmente às medidas de incentivo implementadas, não houve preocupação das autoridades econômicas com o desempenho externo em termos de produtividade, o que acabou sendo problemático quando se observa que ocorreu rápida mudança do paradigma tecno-produtivo no plano internacional. Como consequência, o parque produtivo brasileiro, ao final dos anos 1980 , tornou-se relativamente obsoleto e "organizacionalmente" despreparado para as mudanças que teria de enfrentar com a abertura da economia brasileira.

Nos anos 1990, o enfrentamento do problema da inflação crônica e a plena inserção externa da economia, com reformas econômicas de cunho estrutural para atendimento dessa nova realidade, nortearam a atenção das autoridades econômicas. Os moldes como tal inserção foi realizada e a articulação da política macroeconômica para fins de estabilidade ocasionaram aumento da fragilidade externa: déficit na balança comercial compensados com entrada de capitais externos atraídos pelo diferencial de juros, com todo o ônus que a dependência por tais capitais ocasiona para as economias domésticas. Como resultado, observou-se um período de instabilidade nos níveis de crescimento do PIB e aumento do efeito contágio das crises dos países emergentes, pressionando o governo a alterar o regime macroeconômico adotado pós-Plano Real. Entretanto, cabe destacar que os incentivos gerados pelo novo paradigma de abertura econômica contribuíram, de certa forma, para a relativa modernização da economia e a retomada do crescimento da produtividade, estancados desde os anos 1980. 
Em um segundo momento, a partir das mudanças dos regimes cambial e monetário em 1999, a situação externa melhorou consideravelmente. Isso se reflete em termos de aumentos do saldo acumulado da balança comercial, do balanço de pagamentos em transações correntes e da participação do setor externo na dinâmica do PIB. Contudo, quando analisada qualitativa e quantitativamente, considerando-se o panorama global, verifica-se uma fragilização da inserção externa brasileira pela via do comércio. Ao que tudo sugere, o país não conseguiu se inserir na esfera mais dinâmica dos produtos comercializáveis, em grande parte porque não apresentou uma estratégia de desenvolvimento produtivo relacionada ao setor externo e à própria dinâmica acelerada de mutação do cenário externo (Palma, 2004).

Nesse particular, por um lado, os resultados econômicos externos indicam um ganho de importância do comércio internacional na dinâmica e no funcionamento do sistema produtivo brasileiro nos últimos anos, com algumas mudanças estruturais aparentemente em curso. Por outro, esse movimento não se refletiu no ganho de importância do Brasil enquanto player do comércio global, justamente pelo padrão de especialização das exportações brasileiras, as quais não apresentam o elevado grau de dinamismo dos setores mais intensivos em tecnologia. Ou seja, pode-se afirmar que o aumento da participação do setor externo na economia brasileira nos anos recentes esteve relacionado principalmente com a mudança do regime cambial e, na sequência, por uma melhora do cenário externo. ${ }^{17}$

Diante desse contexto, surgem preocupações com:

i. a elevada elasticidade-renda das importações brasileiras que pode comprometer os megassuperávits quando a economia voltar a crescer de forma sustentável;

ii. a dependência da economia por insumos importados, já que qualquer expansão mais dinâmica da produção industrial tende a pressionar ainda mais as importações; e

iii. a atual tendência de valorização cambial que tanto estimula o aumento de importações quanto arrefece as exportações.

Além disso, o perfil de ingresso de capitais sob a ótica de investimento de risco tem sido nitidamente direcionado para os setores non-tradables, o que tende a comprometer, no futuro, a balança de
${ }_{17}$ Corroborando com essa ideia, a participação das exportações brasileiras nas exportações mundiais não apresentou evolução significativa. Conforme dados da UNCTAD (2009), em 1980 as exportações brasileiras representavam cerca de 0,99\% das exportações mundiais, ao passo que, em 2008, elas elevaram-se tão somente para $1,24 \%$. Ademais, pelas referidas informações, percebese que as menores e maiores participações das exportações brasileiras ocorreram, respectivamente, em 1999 (0,84\%) e em 1984 (1,38\%). Nos anos 2000, a média da razão exportações brasileiras / exportações mundiais foi da ordem de 1,04\%, superior à média dos anos 1990 (0,92\%), mas ligeiramente inferior à média dos anos 1980 (1,14\%). 
serviços quando da remessa de royalties, lucros e dividendos, sem a contrapartida de receitas de exportação. Por esses fatores, entre outros, entende-se que mitigar e/ou eliminar, once and for all, a restrição externa tem de ser uma das prioridades da política econômica, por mais que ela não tenha sido a principal questão da economia brasileira nos últimos anos.

Ao se concentrar na análise no comportamento da dinâmica do setor externo e no crescimento da economia brasileira a partir de 1980, observa-se que, a despeito de a taxa de crescimento do PIB ter sido caracterizada por uma dinâmica à la stop-and-go, em anos nos quais o crescimento do PIB foi pífio, a situação externa deteriorou-se, ao passo que, em anos de crescimento econômico mais "robusto", a situação externa melhorou substancialmente (Gráfico 1, Tabela 1 e Tabela 8).

Indo nessa direção, por um lado, a análise de alguns indicadores de vulnerabilidade externa chama a atenção para a evidência da referida relação:

i. Ao longo da década de 1980, a relação serviço da dívida/exportações, que em 1982 chegou a 101,9\%, diminuiu consideravelmente, chegando a 57,3\% em 1989. Da mesma forma, os juros da dívida sobre as ex- portações registraram uma redução substancial: em 1982 a referida relação era de $60,0 \%$, ao passo que, em 1989, ela chegou a 31,0\%. Por sua vez, enquanto a dívida externa total em relação ao PIB aumentou entre 1980 e 1985, a razão da dívida total sobre as exportações mantevese relativamente estável. A melhora desses indicadores externos, a partir da segunda metade dos anos 1980 , coincide com melhor performance do PIB entre 1985 e 1989: de 1980 a 1984, a taxa média de crescimento do PIB foi da ordem de $1,5 \%$ ao ano, enquanto, no período 19851989, o PIB cresceu a uma média anual de $4,4 \%$;

ii. Na primeira metade da década de 1990, a relação juros da dívida sobre as exportações apresentou tendência de queda, mantendo-se em torno de 20,0\% ao ano. Entretanto, a partir da segunda metade dos anos 1990, essa tendência foi revertida. Em 1999, por exemplo, a razão juros da dívida/exportações elevouse para 33,0\%. Em relação à razão dívida externa/PIB, houve um aumento significativo entre 1994 e 1999, por causa principalmente do baixo dinamismo das exportações, 
em parte decorrente do processo de apreciação da taxa de câmbio. Concomitantemente à deterioração dos indicadores externos, ao longo dos anos 1990, o crescimento do PIB foi pífio: as taxas médias de crescimento entre 1900 e 1994 e 1995 e 1999 foram, respectivamente, 1,2\% ao ano e $2,1 \%$ ao ano;

iii. Os anos 2000, por sua vez, destacamse pelos sucessivos superávits em transações correntes em conjunto com uma estratégia de acúmulo de reservas, o qual se verifica sobretudo pelo comportamento da razão reservas/serviço da dívida, que passou de 0,8 em 2002 para mais de 5,0 em 2008. Ademais, a relação serviço da dívida/exportações verificada em 2008 foi inferior a 20,0\%, isto é, o menor percentual do período em análise. Dessa maneira, nos anos recentes, tanto o aumento das exportações, em relação aos anos 1990 , quanto a estratégia de acúmulo de reservas cooperaram para a redução do grau de vulnerabilidade externa e a melhora nos indicadores de endividamento e liquidez. No que diz respeito ao PIB, nos períodos 20002004 e 2005-2008, as taxas médias anuais de crescimento foram, respectivamente, $3,0 \%$ e $4,5 \%$.
Em suma, a análise acima mostra que, nas décadas de 1980 e 1990, houve, em geral, deterioração dos indicadores de vulnerabilidade externa e baixo crescimento econômico, enquanto, na década de 2000, ocorreu melhora substancial nas contas externas, e o crescimento econômico foi mais dinâmico.

Por outro lado, para mostrar mais especificamente a relação de causalidade entre vulnerabilidade externa e crescimento econômico da economia brasileira entre 1980 e 2008, realizou-se um teste de causalidade de Granger entre a variável Necessidade de Financiamento Externo (NFE) - definida pela soma dos saldos em transações correntes e do IDE líquido, sendo um conceito aceito e difundido tanto na literatura quanto nas bases estatísticas oficiais, tais como BCB e IPEA - e o PIB para o referido período. ${ }^{18}$

Para efeito da análise do teste de causalidade de Granger, consideraram-se:

i. as variáveis NFE e PIB em dólares trimestrais (Tabela 9); e

ii. a escolha do número de defasagens foi feita a partir da estimação de um modelo vetor autorregressivo (VAR), conforme Tabela 10.
18 Em termos metodológicos, a variável $\mathrm{NFE}$ apresentou estacionariedade em nível, ao passo que a variável PIB apresentou ordem de integração 1, de acordo com o teste de Phillips-Perron. Assim sendo, o teste foi realizado com a variável NFE e a variável PIB defasado. 
Tabela 9_ Necessidade de financiamento externo (NFE) e PIB, valores em US\$ milhões trimestrais, 1980-2008

\begin{tabular}{|c|c|c|c|c|c|c|c|c|}
\hline $\begin{array}{c}\text { Ano/ } \\
\text { trimestre }\end{array}$ & NFE & $\begin{array}{c}\text { P|B } \\
\text { trimestral }\end{array}$ & $\begin{array}{c}\text { Ano/ } \\
\text { trimestre }\end{array}$ & NFE & $\begin{array}{c}\text { Ano/ } \\
\text { trimestre }\end{array}$ & $\begin{array}{c}\text { Ano/ } \\
\text { trimestre }\end{array}$ & NFE & $\begin{array}{c}\text { Ano/ } \\
\text { trimestre }\end{array}$ \\
\hline 1980.I & $-3.193,0$ & $54.370,0$ & 1989.IV & 78,0 & 105.682,0 & 1999.III & $3.825,0$ & $150.626,0$ \\
\hline 1980.II & $-2.621,0$ & $60.865,0$ & 1990.I & $-2.749,0$ & $112.084,0$ & 1999.IV & $-1.985,0$ & $151.367,0$ \\
\hline 1980.III & $-3.167,0$ & $61.426,0$ & 1990.II & $1.822,0$ & $111.741,0$ & 2000.I & $2.658,0$ & $151.819,0$ \\
\hline 1980.IV & $-2.215,0$ & $61.111,0$ & 1990.III & $-296,0$ & $125.435,0$ & 2000.II & $-958,0$ & $160.841,0$ \\
\hline 1981.I & $-2.340,0$ & $62.211,0$ & 1990.IV & $-2.196,0$ & $120.058,0$ & 2000.III & $3.872,0$ & $165.547,0$ \\
\hline 1981.II & $-2.468,0$ & $67.106,0$ & 1991.I & 366,0 & $95.976,0$ & 2000.IV & 702,0 & $166.777,0$ \\
\hline 1981.III & $-2.551,0$ & $65.904,0$ & 1991.II & $1.082,0$ & $101.465,0$ & 2001.I & $-2.050,0$ & $133.978,0$ \\
\hline 1981.IV & $-2.032,0$ & $63.333,0$ & 1991.III & $-1.675,0$ & $106.079,0$ & 2001.II & 792,0 & $140.171,0$ \\
\hline 1982.I & $-3.344,0$ & $62.597,0$ & 1991.IV & $-1.093,0$ & $102.159,0$ & 2001.III & 975,0 & $140.526,0$ \\
\hline 1982.II & $-3.464,0$ & $70.708,0$ & 1992.I & $2.098,0$ & $89.001,0$ & 2001.IV & $1.783,0$ & $139.095,0$ \\
\hline 1982.III & $-3.493,0$ & $70.906,0$ & 1992.II & $2.769,0$ & $95.297,0$ & 2002.I & 945,0 & $118.534,0$ \\
\hline 1982.IV & $-3.232,0$ & $67.041,0$ & 1992.III & 780,0 & $100.864,0$ & 2002.II & $-730,0$ & $126.288,0$ \\
\hline 1983.I & $-3.012,0$ & $43.791,0$ & 1992.IV & $2.386,0$ & $102.133,0$ & 2002.III & $2.781,0$ & $129.278,0$ \\
\hline 1983.II & $-787,0$ & $48.900,0$ & 1993.I & $-40,0$ & $99.068,0$ & 2002.IV & $3.475,0$ & $130.259,0$ \\
\hline 1983.III & $-532,0$ & $48.981,0$ & 1993.II & 287,0 & $105.697,0$ & 2003.I & $1.444,0$ & $132.582,0$ \\
\hline 1983.IV & $-1.304,0$ & $47.787,0$ & 1993.III & 133,0 & $112.110,0$ & 2003.II & $1.998,0$ & $138.221,0$ \\
\hline 1984.I & $-206,0$ & $43.472,0$ & 1993.IV & $-257,0$ & $112.811,0$ & 2003.III & $6.715,0$ & $141.024,0$ \\
\hline 1984.II & 607,0 & $48.682,0$ & 1994.I & 806,0 & $122.915,0$ & 2003.IV & $3.915,0$ & $141.776,0$ \\
\hline 1984.III & $1.000,0$ & $48.972,0$ & 1994.II & $1.467,0$ & $129.320,0$ & 2004.I & $4.040,0$ & $157.028,0$ \\
\hline 1984.IV & 154,0 & $48.618,0$ & 1994.III & $2.274,0$ & $142.203,0$ & 2004.II & $3.562,0$ & $168.739,0$ \\
\hline 1985.I & $-929,0$ & $47.932,0$ & 1994.IV & $-4.899,0$ & $148.649,0$ & 2004.III & $5.498,0$ & $168.084,0$ \\
\hline 1985.II & 820,0 & $53.053,0$ & 1995.I & $-5.291,0$ & $183.943,0$ & 2004.IV & $6.918,0$ & $169.932,0$ \\
\hline 1985.III & 877,0 & $55.049,0$ & 1995.II & $-5.847,0$ & $191.863,0$ & 2005.I & $5.203,0$ & $207.622,0$ \\
\hline 1985.IV & 321,0 & $55.057,0$ & 1995.III & $-1.456,0$ & $196.432,0$ & 2005.II & $6.779,0$ & $222.965,0$ \\
\hline 1986.I & $-624,0$ & $59.109,0$ & 1995.IV & $-2.480,0$ & $198.113,0$ & 2005.III & $8.210,0$ & $224.688,0$ \\
\hline 1986.II & 354,0 & $64.669,0$ & 1996.I & $-461,0$ & $194.317,0$ & 2005.IV & $6.343,0$ & $227.164,0$ \\
\hline 1986.III & $-938,0$ & $67.421,0$ & 1996.II & $-590,0$ & $206.849,0$ & 2006.I & $2.480,0$ & $258.326,0$ \\
\hline $\begin{array}{l}1986 . \mathrm{IV} \\
\ldots \ldots \ldots \ldots\end{array}$ & $\begin{array}{l}-3.942,0 \\
\ldots \ldots \ldots \ldots \ldots\end{array}$ & $66.612,0$ & 1996.III & $\begin{array}{c}-4.643,0 \\
\ldots \ldots \ldots \ldots\end{array}$ & $222.290,0$ & 2006.II & $\begin{array}{l}3.172,0 \\
\ldots . \ldots .\end{array}$ & $271.746,0$ \\
\hline
\end{tabular}


Tabela 9_ Necessidade de financiamento externo (NFE) e PIB, valores em US\$ milhões trimestrais, 1980-2008

\begin{tabular}{|c|c|c|c|c|c|c|c|c|}
\hline $\begin{array}{c}\text { Ano/ } \\
\text { trimestre }\end{array}$ & NFE & $\begin{array}{c}\text { PIB } \\
\text { trimestral }\end{array}$ & $\begin{array}{c}\text { Ano/ } \\
\text { trimestre }\end{array}$ & NFE & $\begin{array}{c}\text { Ano/ } \\
\text { trimestre }\end{array}$ & $\begin{array}{c}\text { Ano/ } \\
\text { trimestre }\end{array}$ & NFE & $\begin{array}{c}\text { Ano/ } \\
\text { trimestre }\end{array}$ \\
\hline 1987.I & $-2.429,0$ & $66.347,0$ & 1996.IV & $-6.547,0$ & $216.812,0$ & 2006.III & $8.793,0$ & $279.588,0$ \\
\hline 1987.II & $-144,0$ & $73.087,0$ & 1997.I & $-1.759,0$ & $203.347,0$ & 2006.IV & $-10.183,0$ & $279.107,0$ \\
\hline 1987.III & $1.688,0$ & $71.984,0$ & 1997.II & $-3.396,0$ & $217.800,0$ & 2007.I & $8.742,0$ & $320.158,0$ \\
\hline 1987.IV & 479,0 & $70.939,0$ & 1997.III & $-2.637,0$ & $226.219,0$ & 2007.II & $17.957,0$ & $341.637,0$ \\
\hline 1988.I & $-233,0$ & $71.828,0$ & 1997.IV & $-4.783,0$ & $223.908,0$ & 2007.III & $8.128,0$ & $349.331,0$ \\
\hline 1988.II & $2.818,0$ & $78.739,0$ & 1998.I & $-2.328,0$ & $198.313,0$ & 2007.IV & $-5.758,0$ & $355.418,0$ \\
\hline 1988.III & $2.944,0$ & $79.809,0$ & 1998.II & $-1.342,0$ & $214.098,0$ & 2008.I & $-5.914,0$ & $393.466,0$ \\
\hline 1988.IV & $1.280,0$ & $75.331,0$ & 1998.III & $-320,0$ & $218.992,0$ & 2008.II & $-2.826,0$ & $414.511,0$ \\
\hline 1989.I & $1.198,0$ & $92.012,0$ & 1998.IV & $-3.425,0$ & $212.582,0$ & 2008.III & $1.304,0$ & $424.430,0$ \\
\hline 1989.II & 636,0 & $107.708,0$ & 1999.I & $1.539,0$ & $137.589,0$ & 2008.IV & $3.845,0$ & $403.614,0$ \\
\hline 1989.III & $-274,0$ & $110.514,0$ & 1999.II & $-1.826,0$ & $147.195,0$ & - & - & - \\
\hline
\end{tabular}

Fonte: Banco Central do Brasil.

Em relação ao critério de defasagem, os testes de Schuwartz e de Hanna-Quin indicaram que a defasagem temporal que mais se adequou à análise de causalidade entre a NFE e o PIB, tal que a NFE influencia o comportamento do PIB, foi o espaço de quatro trimestres. Em outras palavras, a variável NFE apresenta uma causalidade de Granger (Granger causa) sobre a variável do PIB defasado, sendo estatisticamente significante para o nível de 1,0\% de confiança (Tabela 11). ${ }^{19}$

Por sua vez, adotando-se o teste de Akaike (Tabela 12), que sugere como adequado 8 lags, ou seja, um espaço de oito trimestres, tanto o PIB defasado tem impacto sobre a NFE quanto a NFE influencia o PIB, o que remete à hipótese de Thirlwall (1982), de que o crescimento acima da taxa de equilíbrio do balanço de pagamentos pode gerar uma situação de necessidade de financiamento externo, uma vez que eleva a demanda por importações.

As evidências estatísticas e econométricas sobre a relação entre vulnerabilidade externa e crescimento econômico para a economia brasileira, acima apresentadas, vão ao encontro dos argumentos de diversos autores de que o crescimento econômico é sensível à vul-
Com o P-valor de 0,005, não se aceita a hipótese-nula de que a NFE não apresenta causalidade de Granger com o PIB defasado. 
Tabela 10_Escolha da defasagem

\begin{tabular}{|c|c|c|c|}
\hline Lag & Akaike & Schuwartz & Hanna-Quin \\
\hline 0 & 41,2612 & 41,31175 & 41,28168 \\
\hline 1 & 41,09568 & 41,24734 & 41,15713 \\
\hline 2 & 41,12247 & 41,37523 & 41,22489 \\
\hline 3 & 41,08121 & 41,43507 & 41,2246 \\
\hline 4 & 40,75822 & $41,21319 *$ & $40,94258^{*}$ \\
\hline 5 & 40,80276 & 41,35883 & 41,02809 \\
\hline 6 & 40,73727 & 41,39444 & 41,00356 \\
\hline 7 & 40,74170 & 41,49998 & 41,04897 \\
\hline 8 & $40,68871^{*}$ & 41,54808 & 41,03694 \\
\hline 9 & 40,72789 & 41,68837 & 41,11709 \\
\hline 10 & 40,79609 & 41,85767 & 41,22626 \\
\hline
\end{tabular}

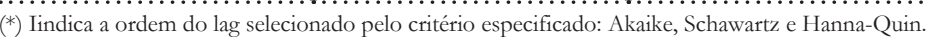

Fonte: Elaboração dos autores com base na saída do EVIEWS 5.

Tahela 11_Teste de Causalidade de Granger (Lag $=4$ )

\begin{tabular}{|c|c|c|c|}
\hline Hipótese Nula & Observação & F-Statistic & Probabilidade \\
\hline PIB não é "Granger Cause" NFE & 111 & 0,45527 & 0,76835 \\
\hline NFE não é "Granger Cause" PIB & - & 3,95861 & 0,005 \\
\hline
\end{tabular}

Fonte: Elaboração dos autores com base na saída do EVIEWS 5.

Tabela 12_Teste de Causalidade de Granger ( $\operatorname{Lag}=8$ )

\begin{tabular}{|c|c|c|c|}
\hline Hipótese Nula & Observação & F-Statistic & Probabilidade \\
\hline PIB não é "Granger Cause" NFE & 107 & 3,11521 & 0,00376 \\
\hline NFE não é "Granger Cause" PIB & - & 2,02185 & 0,05252 \\
\hline
\end{tabular}

Fonte: Elaboração dos autores com base na saída do EVIEWS 5. 
nerabilidade externa e também ao financiamento externo, favorecido pelo elevado grau de abertura, que são pró-cíclicos por natureza e condicionam a adoção de um regime interno de políticas econômicas, igualmente pró-cíclicos. Ou seja, com maior integração econômica, a margem de manobra para adoção de políticas econômicas fica significativamente diminuída, conforme o grau de abertura da economia (Ocampo, 2002; Stiglitz, 2002). Segundo Rodrik (2002), as evidências empíricas mostram que os países que tiveram melhor desempenho na implantação das chamadas "reformas estruturais" foram aqueles que souberam combinar diversos componentes na formulação de sua estratégia de inserção externa e não aqueles que simplesmente "aguardaram" que a liberalização se encarregasse de deslanchar os investimentos geradores de crescimento.

Nesse sentido, a estratégia nacional para lidar com a globalização deve ter em conta, por um lado, a extrema importância da manutenção da estabilidade macroeconômica e a adoção de políticas contracíclicas, como forma de reduzir a vulnerabilidade e facilitar o investimento produtivo (Ocampo, 2002). O crescimento volátil faz com que a economia conviva com um processo de subutili- zação da capacidade produtiva, diminui a produtividade e o lucro e afeta adversamente o investimento, o que deprime o crescimento de longo prazo. Por outro, não se deve descuidar das medidas de incentivo ao setor externo. Isso porque, como afirma Thirlwall (2005), as exportações diferem dos outros componentes da demanda agregada, sobretudo porque são os únicos componentes da demanda autônoma de um sistema econômico, no sentido de provir de fora do sistema. Além disso, elas são capazes de custear os requisitos de importação para o crescimento econômico de longo prazo, uma vez que esses podem ser mais produtivos que os recursos internos, como, por exemplo, bens de capital.

Portanto, na busca de uma trajetória de crescimento econômico sustentável, a fim de superar as dificuldades impostas pelas restrições externas, devese ter em conta, além do regime macroeconômico favorável ao investimento, como previamente mencionado, medidas que envolvem a transformação das estruturas de produção, como:

i. adoção de uma taxa de câmbio em conformidade com o mecanismo operacional de um sistema cambial administrado, de tal forma que não somente as ações especulativas pos- 
sam ser coibidas, mas a taxa real de câmbio mantenha-se relativamente estável ao longo do tempo, sendo até favorável à atividade exportadora;

ii. uma política de promoção e diversificação das exportações, tanto em termos de pauta de produtos exportados quanto destino delas;

iii. aumento do vínculo entre a produção interna e aquela voltada para o mercado internacional, em que o IDE representa papel fundamental, considerando uma política estratégica de atração desses investimentos;

iv. esforços para aumentar o número de empresas que exportam (pequenas e médias, além das grandes);

v. apoio à formação de clusters, incluindo as PMEs nas atividades relacionadas à produção para o mercado internacional;

vi. redução das restrições tarifárias e não tarifárias existentes aos produtos brasileiros;

vii. investimento em infraestrutura e aperfeiçoamento do arcabouço institucional e logístico (Baumann, 2002);

viii. pesquisa e tecnologia.
Em síntese, em longo prazo, a única solução segura para elevar a taxa de crescimento de um país, em consonância com o equilíbrio do balanço de pagamentos em conta-corrente, é a mudança estrutural no sentido de aumentar a elasticidade-renda de exportações e diminuir a elasticidade-renda por importações (Thirlwall, 2005). Assim sendo, no plano microinstitucional, são imprescindíveis tanto políticas industriais para dinamizar o volume de comércio exterior, por meio principalmente do aumento da competitividade da estrutura produtiva (Kupfer, 2005), quanto uma política que vise à atração de IDE capaz de alterar a elasticidade-renda das exportações e das importações (Lima, 2005).

Nesse sentido, uma política comercial ativa, com o objetivo de se ter tarifas e instrumentos não tarifários, como políticas de crédito e financiamento, é fundamental para que a política industrial reestruture as exportações e substitua as importações, mantendo aquelas que contribuirão para o nível de produtividade da economia. Ademais, políticas comerciais estratégicas e mecanismos eficientes de regulamentação e de estímulos para setores industriais dinâmicos que operem à escala internacional, sob condições de retornos crescen- 
tes que gerem externalidade tecnológica, são essenciais para expandir as exportações (Chang, 2003 e Palma, 2004).

Por sua vez, no plano macroeconômico, além de políticas fiscal e monetária contracíclicas, não se pode deixar de lado a ideia de se buscar uma taxa de câmbio real de equilíbrio que não gere pressões inflacionárias e desestabilize o balanço de pagamentos. Para tanto, câmbio administrado e regulação dos fluxos de capitais são fundamentais. Nesse particular, Ferrari Filho e Paula (2006, p. 190) apontam que os mecanismos de controle de capitais podem ocorrer de três formas:

i. controles diretos ou administrados, ou seja, restrição quantitativa de fluxos de capitais conforme suas origens, maturidade e destinações;

ii. controles indiretos ou baseados em preços, que são estabelecidos pela cobrança de impostos sobre fluxos de capitais entre países e/ou pela imposição de depósitos compulsórios incidentes sobre os fluxos de capitais ingressantes; $\mathrm{e}$

iii. regulações financeiras, isto é, imposição de limites sobre posições cambiais de residentes.

\section{4_Conclusão}

Como foi visto, nos anos 1990 e, mais especificamente, a partir do Plano Real, a política de incentivos às exportações foi preterida na agenda econômica, uma vez que as atenções voltaram-se para a estabilização monetária. Naquela ocasião, seguindo a lógica dos programas de estabilização baseados em âncora cambial e liberalização comercial e financeira, os resultados da política econômica foram auspiciosos sob a ótica do controle inflacionário e desastrosos sob as óticas de crescimento econômico e de equilíbrio externo, já que as taxas de crescimento observadas ao longo do referido período foram pífias e instáveis, e o grau de vulnerabilidade externa expôs a economia brasileira a sucessivas situações de crises cambiais. Além disso, tal estratégia de política econômica adotada no Plano Real gerou a armadilha do crescimento econômico, qual seja: a redução da inflação e a apreciação cambial arrefeceram as exportações e incentivaram a demanda por importações, cuja consequência foi a redução do superávit comercial e, por conseguinte, o agravamento do déficit em transações correntes, limitando, assim, a própria dinâmica de crescimento da economia. 
20 As crises cambiais dos países emergentes nos anos 1990 e início dos anos 2000, entre as quais as do Brasil em 1998-1999 e 2002, e a recente crise do subprime são exemplos de choques externos que acabam limitando a dinâmica de crescimento da economia brasileira.

21 Ao final de 2008, elas encontravam-se ao redor de US\$194,0 bilhões (Tabela 7).

22 Sobre a lógica de políticas macroeconômicas de cunho keynesianas, veja Arestis e Sawyer (1988) e Davidson e Davidson (1996).
A despeito da falta de uma estratégia efetiva de crescimento das exportações nos últimos anos, a reversão dos saldos comerciais e a ligeira recuperação do crescimento da economia brasileira denotam a importância dos resultados externos para o desempenho da economia. Contudo, a falta de um conjunto de políticas articuladas que visem a uma inserção externa ativa pode gerar, em um futuro próximo, um quadro propício para um novo período tanto de recrudescimento da vulnerabilidade externa quanto de baixo crescimento econômico e volátil, características da economia brasileira na década de 1990 e começo dos anos 2000 .

Assim sendo, o crescimento econômico autossustentável somente poderá ser assegurado quando o país, definitivamente, não estiver vulnerável a choques externos que, além de desequilibrarem o balanço de pagamentos, restringem o crescimento econômico. ${ }^{20}$ Nesse sentido, por mais que as reservas cambiais brasileiras encontrem-se em situação confortável, ${ }^{21}$ a eliminação da restrição externa do país - isto é, déficits de balanço de pagamentos em transações correntes financiados por "poupança externa" - não pode prescindir das seguintes medidas: i. adoção de uma política comercial mais dinâmica e articulada com a política industrial com o intuito de promover tanto a exportação de bens e serviços quanto a substituição de produtos - subentende-se políticas tarifária e de crédito que visem ao controle de importações, tendo em vista que elas são necessárias para o bom desempenho produtivo -;

ii. administração da taxa de câmbio, visto que essa é uma variável macroeconômica-chave, que, interagindo com as políticas monetária e fiscal, afeta o balanço de pagamentos, os preços e os níveis de atividade e emprego; e

iii. implementação de instrumentos que regulem os fluxos de capitais, de maneira que esses possam prevenir crises de balanço de pagamentos. Adicionalmente, políticas macroeconômicas de cunho keynesiana, 22 fiscal e monetária não podem ser negligenciadas. 


\section{Referências bibliográficas}

\author{
ARESTIS, P.; SAWYER, M.. \\ Keynesian economic policies \\ for the new millennium. \\ The Economic Journal, n. 108, \\ p. 181-195, Jan. 1988.
}

BAUMANN, R.. Os desafios da exportação. In: CASTRO, A. C. (Org.). Desenvolvimento em debate: painéis do desenvolvimento brasileiro I. Rio de Janeiro: BNDES-MAUAD, 2002. p. 105-130.

BRASIL. Banco Central do Brasil. 2009. Disponível em: <http:// www.bacen.gov.br>. Acesso em: 15 nov. 2009

BRASIL. Instituto Brasileiro de Geografia e Estatística. 2009. Disponível em: <http://www. ibge.gov.br>. Acesso em: 15 nov. 2009.

BRASIL. Instituto de Pesquisa Econômica Aplicada. 2009. Disponível em: <http://www. ipeadata.gov.br>. Acesso em: 15 nov. 2009.

BRASIL. Ministério do Desenvolvimento, Indústria e Comércio Exterior, Secretaria de Comércio Exterior, 2009. Disponível em: <http://www. mdic.gov.br>. Acesso em: 15 nov. 2009.
BRASIL. Ministério da Fazenda, Receita Federal, 2009. Disponível em: <http://www.receita.fazenda. gov.br>. Acesso em: 15 nov. 2009

\section{CASTRO, A. B.; PIRES DE}

SOUZA, F. E. A economia brasileira em marcha forçada. Rio de Janeiro: Paz e Terra, 1985.

CHANG, H. J. Globalization, economic development and the role of the State. Penang/Malaysia: Third World Network, 2003.

DAVIDSON, G.; DAVIDSON, P. Economics for a civilized society. New York: M. E. Sharpe, 1996.

FERRARI-FILHO, F.; PAULA, L. F. The legacy of the Real Plan and an alternative agenda for the Brazilian economy. Investigación Econômica, 42, n. 244, p. 57-92, abril-junio 2003.

FERRARI-FILHO, F.; PAULA, L. F. Regime cambial, conversibilidade da conta capital e performance econômica: a experiência recente de Brasil, Rússia, Índia e China. In: FERRARI FILHO, F.; SICSÚ, J. (Org.). Câmbio e controle de capitais: avaliando a eficiência de modelos macroeconômicos. Rio de Janeiro: Campus-Elsevier, 2006.

p. $184-221$.
GONÇALVES, R. Economia Política Internacional: fundamentos teóricos e as relações internacionais do Brasil. Rio de Janeiro: Elsevier, 2005.

KUPFER, D. Política industrial, infra-estrutura e inovação. In: CAVALCANTI, B.; RUEDIGER, M.; SOBREIRA, R. (Orgs.).

Desenvolvimento e construção nacional. Rio de Janeiro: FGV e Konrad Adenauer, 2005. p. 129-144.

LIMA, G. T. Restrição externa e investimento direto estrangeiro no Brasil. In: CAVALCANTI, B.; RUEDIGER, M.; SOBREIRA, R. (Orgs.). Desenvolvimento e construção nacional. Rio de Janeiro: FGV e Konrad Adenauer, 2005. p. 39-61

OCAMPO, J. A. Globalização e desenvolvimento. In: BNDES.

Desenvolvimento e globalização: perspectivas para as nações. 2002. Disponível em: <http://www. bndes.gov.br/conhecimento/ livro_debate/1-Desenv\&Glob. pdf>. Acesso em: 20 set. 2009.
PALMA, G. Gansos voadores e patos vulneráveis: a diferença da liderança do Japão e dos Estados Unidos no desenvolvimento do Sudeste Asiático e da América Latina. In: FIORI, J. L. (Org.). O poder americano. Petrópolis: Vozes, 2004. p. 393-454.

PAULA, L. F.; ALVES JUNIOR, A. J. Fragilidade financeira externa e os limites da política cambial no real. Revista de Economia Politica, v. 19, n. 1, p. 73, jan./mar. 1999. PRATES, D. M. As assimetrias do sistema monetário e financeiro internacional. Revista de Economia Contemporânea, v. 9, n. 2, p. 263-288, maio/ago. 2005.

\section{RODRIK, D. Depois do} neoliberalismo, o quê? In: BNDES. Desenvolvimento e globalização: perspectivas para as nações, 2002. Disponível em: <http://www.bndes.gov.br/ conhecimento/livro_debate/1Desenv\&Glob.pdf > . Acesso em: 15 set. 2009. 
STIGLITZ, J. E. Políticas de desenvolvimento no mundo da globalização. In: BNDES. Desenvolvimento e globalização: perspectivas para as nações. 2002. Disponível em:

$<$ http://www.bndes.gov.br/ conhecimento/livro_debate/1-

Desenv\&Glob.pdf $>$. Acesso em: 15 set. 2009.

THIRLWALL, A. P. Trade, the balance of payments and exchange rate policy in developing countries. Northampton: Edward Elgar, 1982.

THIRLWALL, A. P. A natureza do crescimento econômico: um referencial teórico para compreender o desempenho das nações. Brasília: IPEA, 2005.

\section{UNITED NATIONS}

CONFERENCE ON TRADE

AND DEVELOPMENT

(UNCTAD) (2009). Disponível

em: <http://www.unctad.org>. Acesso em: 15 nov. 2009.

VEIGA, P. M. Política comercial, indústria e exportações: vamos voltar a falar de produtividade e competitividade? In: CASTRO, A. C. (Org.). Desenvolvimento em debate: painéis do desenvolvimento brasileiro I. Rio de Janeiro: BNDES-MAUAD, 2002. p. 81-104.

WORLD BANK. Global Economic Prospects and the Developing Countries.

Washington: World Bank, 2002.

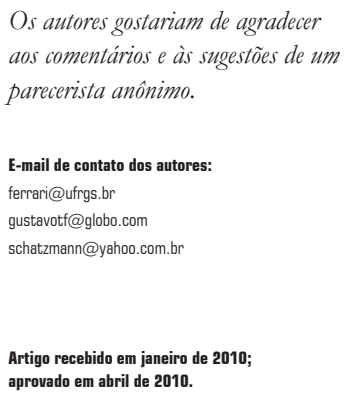


